\title{
Firms' performance during the COVID-19 outbreak: international evidence from 13 countries
}

\section{Olga Golubeva}

\begin{abstract}
Purpose - The purpose of this paper is to explore the impact of firm-, finance- and country-specific indicators to the performance of companies under the COVID-19 outbreak.

Design/methodology/approach - The study uses a regression performance model for enterprises during the COVID-19 crisis. The investigation is based upon a data set of 5,730 firms from 13 countries collected by the World Bank through enterprise surveys. The author combined the analysis of traditional performance measurements with the testing of relatively novel variables.

Findings - This study confirms the significance of multiple factors for company performance: sector, size, participation in exports and market demand for firms' products. Robust financing solutions during the coronavirus pandemic period include equity contributions, followed by firms' cash balances and debt. Support by a government, however, has not yet been confirmed as a significant source of finance. This paper also suggests the importance of country-specific factors for the performance of enterprises, including the level of economic development and the corporate governance infrastructure.

Practical implications - The research outcomes might assist regulatory bodies, policymakers and companies in their formulation of public and corporate governance strategies concerning future emergency preparedness and responses.
\end{abstract}

Originality/value - This paper is among the first empirical studies in the management realm that addresses the impact of COVID-19 on company performance, with cross-national empirical data.

Keywords Company performance, Financial sources, COVID-19, Country-specific factors, Firm-specific indicators

Paper type Research paper

\section{Introduction}

In March 2020, the World Health Organisation (WHO) declared that a coronavirus outbreak (COVID-19) was a pandemic. Overall, this disease, suggested as being linked to a seafood market in Wuhan, capital city of Hubei province in China (Sohrabi et al., 2020), had infected over 101.5 million people and resulted in more than 2.1 million deaths by 30 January 2021 (World Health Organisation (WHO), 2021). The 20th century had already witnessed two pandemics since the historic "Spanish Influenza" of 1918: the "Asian flu" of 1957 and the 1968 "Hong Kong flu". The 21st century has seen four further pandemic outbreaks: SARS in 2002; "bird flu" in 2009; MERS in 2012; and Ebola which peaked in 2013-2014 (Baldwin and Weder di Mauro, 2020).

Considering such a repetitive pattern of pandemics, one might wonder why an explosion of COVID-19 is a distinctive and notable phenomenon. Does this coronavirus outbreak differ sufficiently enough from other pandemics and natural disasters as to constitute a special case for academic research? In addition, exactly how are private firms navigating the economic disruptions resulting from the spread of COVID-19 and worldwide lockdowns?
Olga Golubeva is based at Stockholm Business School, Stockholm University, Stockholm, Sweden.

Received 11 September 2020 Revised 9 February 2021 27 February 2021

Accepted 1 March 2021

Olga GolubevaPublished by Emerald Publishing Limited. This article is published under the Creative Commons Attribution (CC BY 4.0) licence. Anyone may reproduce, distribute, translate and create derivative works of this article (for both commercial and non-commercial purposes), subject to full attribution to the original publication and authors. The full terms of this licence maybe seen at http://creativecommons.org/licences/by/4.0/ legalcode

The author of the paper would like to express gratitude to Professor Gabriel Eweje and anonymous peer-reviewers for their valuable suggestions and general guidance during the review process. The author is also indebted to Dr Alan Wood (UK) for proofreading assistance. 
Which factors are most appropriate for assessing the effects of COVID-19 on company performance?

Organisations often face crises, but the COVID-19 pandemic may be unique given its speed of change and the scale of its impact on both private and public segments of the economy (Mather, 2020; Kells, 2020). The COVID-19 outbreak has triggered a \$2.2tn bailout package in the USA versus that country's \$750bn package during the previous global financial crisis (Bongini et al., 2019). This response greatly exceeds the economic effects which arose from the 1918 "Spanish Influenza" epidemic, according to Barro et al. (2020).

While there have been numerous studies which focus on past events that roughly parallel the consequences of the COVID-19 pandemic, there is an additional avenue to investigate: How business mobilisation may differ in responding to the unprecedented scale of the pandemic crisis. The early literature highlights both the enormous economic and social impacts of the COVID-19 outbreak with respect to financial markets, institutions and public policy (Goodell, 2020; lyke, 2020; He and Harris, 2020). It also examines the effect that this pandemic might have on organisations facing such challenging strategic decisions as balancing employee and public health protections against operational costs and financial returns (Parker, 2020; Rinaldi et al., 2020).

This paper explores the impact of firm-, finance- and country-specific indicators to the performance of companies under the COVID-19 outbreak. This paper examines the recent scant academic research regarding the impact of coronavirus pandemics alongside literature on past events that, in some ways, are approximately comparable with COVID-19 (like previous epidemics, economic shocks and financial crises).

Our paper adds to the current research on firms' performance as follows: firstly, a coronavirus outbreak provides a unique setting of extreme uncertainty in which to examine the performances of companies. The primary contribution of the study is the conceptualisation of a performance model for enterprises during the COVID-19 crisis.

Secondly, this devastating outlier event itself questions the suitability of current performance measurements commonly applied by companies. In this paper, we combine investigation of traditional performance measurements with the testing of relatively novel variables (such as business closures during COVID-19 and whether firms respond to the pandemic by adjusting their business activities).

Thirdly, the COVID-19 pandemic has raised awareness of the importance of multiple factors that impact firms' performance (Kells, 2020; Obrenovic et al., 2020). Accordingly, we respond to this call by investigating the link between company performance and firmspecific characteristics; financial sources; and country-specific factors. To our knowledge, this study is the first to investigate the simultaneous impact of indicators, drawn from multiple theories, on firms' performances during the coronavirus pandemic.

Finally, given that the COVID-19 crisis extends across different countries, our study analyses a data set, collected by the World Bank Enterprise Surveys (WBES) for 13 countries: Albania, Chad, Cyprus, Georgia, Greece, Guinea, Italy, Moldova, Niger, Russia, Togo, Zambia and Zimbabwe [1]. Our study is among the first to apply an international balanced data set, compiled with the intention of being representative with respect to firm size, business sector and geographic region (see Chapter 3).

The paper reports that sector, firm size, participation in exports and market demand for companies' products may all impact company performance during the COVID-19 outbreak. The empirical evidence suggests that equity contributions, followed by firms' cash balances and debt financing, are among the more robust solutions during the coronavirus pandemic period. Support by a government, however, has not materialised as a significant financing source. In view of funds being established by governments to help firms during the pandemic, 
this question requires additional attention by future scholars. The study also confirms the importance of country-specific characteristics, including the levels of economic development and corporate governance infrastructure in a particular country.

The remainder of the article is structured as follows: firstly, we review the literature relevant to the topic and formulate hypotheses. Secondly, we introduce the methodology. Thirdly, we present the results of the OLS regression. The concluding part summarises the main outcomes of the study.

\section{Literature review and hypotheses development}

\subsection{Measuring company performance under COVID-19 conditions}

Although company performance is of central interest to firms, policymakers and researchers, little convergence of opinion regarding its definition and measurement has yet been demonstrated (Devinney et al., 2010). A firm's performance appears to be a multidimensional concept, meaning that it is composed of different theoretical and empirical components that may (or may not) be related to one another. This point is well-recognised in corporate governance (Fernández-Temprano and Tejerina-Gaite, 2020), management accounting (Chen and Chen, 2011; Melnyk et al., 2014) and finance (Henri, 2004). Current research agendas encourage scholars to step back from focussing only on specific aspects of corporate performance and, instead, adopt a more comprehensive and creative approach (Ferreira and Otley, 2009; Giovannoni and Pia Maraghini, 2013). Indeed, Melnyk et al. (2014) point out that, in today's dynamic and turbulent world, changes in either the business environment or the company strategy may create the need to revise its measures of performance.

The question of which indicators and measures most adequately reflect the performance of firms during the COVID-19 outbreak is a challenging one because this crisis might represent a new set of uncertainties for companies (Kraus et al., 2020). During past shocks - like the Great East Japan Earthquake in 2011, or local flus - the effects on firms were roughly understood within a short period of time. A quite reliable determinant was the companies' locations in relation to the epicentre of the disaster event (Baldwin and Weder di Mauro, 2020). In contrast, the effects of the COVID-19 outbreak are not necessarily dictated by the geographical distance from Wuhan, China. Additionally, a single air crash disaster depresses a particular airline company while the spread of COVID-19 has devastated the entire industry worldwide (Bongini et al., 2019).

The COVID-19 pandemic presents an interesting scenario whereby an unexpected shock causes acute changes in firms' performances relative to the managers' expectations which were held just a few months prior to the crisis (Larcker et al., 2020). International business scholars have started to explore the key factors impacting enterprises' operations and their initial strategies to overcome adversity during the COVID-19 pandemic (Obrenovic et al., 2020). Currently, there are very few academic studies which consider the possible impacts of COVID-19 contagion upon companies' performances. The suspension of operations, disruptions in business activities and closures of firms were among those reported (Larcker et al., 2020).

A sustainable business model may be that of a survival model (Obrenovic et al., 2020). Bartik et al. (2020) started their survey investigating the impact of COVID-19 on American firms by asking owners whether their business was currently operational. A total of $43 \%$ of businesses were reported as being closed and nearly all of the closures were because of the COVID-19 outbreak, demonstrating the poor survivability of these firms. On the other hand, while the economic downturn has adversely impacted many enterprises, certain companies have been able to continue operations - and even prosper - during the COVID-19 pandemic (Obrenovic et al., 2020). Early research has also reported that the corporate performance of organisations is profoundly affected on the revenue side, bringing their sustainability into question (Kells, 2020; Larcker et al., 2020). Companies which continue to be 
agile and to adapt and change production and sales proactively, will arguably have higher chances of thriving in the next normal reality (Mather, 2020).

Few authors continue to apply traditional performance measurements during the COVID-19 pandemic, where a return on assets (ROA) seems to be the most common proxy chosen by scholars (Shen et al., 2020; Zaid et al., 2020). On the other hand, serious concerns have been expressed about whether the regular performance measures do sufficiently reflect the unique environments and rapid changes. Xiong et al. (2020), for example, argue for the application of the cumulative abnormal return over a certain time interval to measure the impact of the COVID-19 pandemic on stock performance.

Although the authors of this paper do not neglect the importance of traditional performance measurements such as profitability margin or ROA, our literature review suggests that a search for new metrics reflecting the capacity of the business model to remain sustainable during such a disruption event seems to be justified.

\subsection{Firm-specific indicators and company performance under COVID-19 conditions}

Almost every company in the world has been affected by the COVID-19 outbreak in one way or another (Kraus et al., 2020). Nevertheless, pandemics might influence different portions of the economic spectrum to varying degrees; such groupings might experience particular ramifications. Early literature about the impact of the COVID-19 pandemic on companies does identify variable effects upon different firm-specific groupings (Al-Awadhi et al., 2020; Shen et al., 2020; Xiong et al., 2020; Zaid et al., 2020).

There is some evidence that the COVID-19 pandemic impacts certain sectors in the economy more than others (Bongini et al., 2019; Al-Awadhi et al., 2020; Shen et al., 2020; Hassan et al., 2020). Bartik et al. (2020) have found that retail businesses are particularly vulnerable to coronavirus-related disruptions. Baldwin and Weder di Mauro (2020), however, warn that the manufacturing sector is likely to receive extra blows from the spread of COVID-19 infection. Additionally, the negative effects of the pandemic in China have been more pronounced in tourism and catering; these industries became the economic "epicentre" of the pandemic's impact (Shen et al., 2020).

Several scholars indicate that a positive relationship exists between size indicators and profitability. Big firms have more competitive power compared to small firms because of a larger market share, better access to capital, experience and operational efficiencies (Ichev and Marinč, 2018). In the same vein, Baldwin and Weder di Mauro (2020) argue that smaller firms may be among those that are most exposed to the impact of the COVID-19 pandemic. Levy (2020) reports that coronavirus-related restrictions have increased the revenues of large technological and pharmaceutical companies while hurting or bankrupting many smaller companies which are more reliant on the traditional economy.

A striking feature of many financial crises is the collapse of exports relative to output (Amiti and Weinstein, 2011). Van Biesebroeck et al. (2016), however, argue that the decline of export sales by existing exporters can be mitigated by supporting mechanisms, including trade-financing facilities. Despite theoretical and empirical inconsistences in research outcomes, the evaluation of companies' share of export in total production as a firm-specific characteristic seems to be rather common in performance assessments (Carneya et al., 2019).

The theory of crisis management was developed with the initial idea that organisations confronted with unstable and unforeseeable environments should establish teams consisting of all those business units that can adjust to severe challenges (Marsden, 2010). The previous financial crisis of 2007-2009 demonstrated that firms should not believe in the idea that free markets guarantee a stable performance but neither should they rely upon 
government donations to solve their problems. An improved self-governance from companies themselves during crisis is critical (Mather, 2020).

A positive phenomenon evident from responses to the COVID-19 crisis has been the speed at which many enterprises have transformed their operations to create efficiencies through the rapid uptake of technology and alternative revenue streams (Obrenovic et al., 2020). One study, conducted by Kraus et al. (2020), presented evidence on how family firms in five European countries were coping with the coronavirus crisis. Their findings show that companies in all industries and of all sizes can adapt their business models to changing conditions within a short period of time.

\subsection{Financial sources and company performance under COVID-19 conditions}

Early business studies stress the importance of financial factors for company performance during the coronavirus outbreak. PWC (2021) emphasises that companies should give special attention to cash flow management, banking arrangements and refinancing. Kells (2020, p. 631) suggests that "cash accounting and the cash position of organisations suddenly became matters of extraordinary concern".

Several rival theories of capital structure attempt to explain companies' financing decisions. The pecking order theory (Myers, 1984; Myers and Majluf, 1984) predicts that, because of asymmetric information, firms prefer internal sources followed by loans and turn to more expensive equity financing only as a last resort. The static trade-off theory states that a value-maximising firm will have a target debt ratio resulting from a trade-off between the benefits of interest payment tax deductions (Miller, 1977) and financial distressed costs (Kraus and Litzenberger, 1973). The agency theory, initially elaborated by Jensen and Meckling (1976), suggests that debt improves the relationship between managers and stockholders because it limits the discretion of managers to overinvest the available free cash flow.

Arguments using capital structure theories remain controversial in current literature and research related to financial decisions has produced mixed results (Fama and French, 2002; Zaid et al., 2020). Investigations of the pecking order theory in cases where a firm faces asymmetric information (yet is not constrained by debt capacity or distress concerns) found evidence that this theory is never able to accurately predict even half of firms' financing decisions (Leary and Roberts, 2010). Additionally, De Jong et al. (2010) concluded that small firms do not behave according to the pecking order theory. Studies examining the capital structure theories during the recent financial crisis of 2007-2009 argue that the trade-off theory is a dominant one in a crisis environment (Chatzinas and Papadopoulos, 2018).

The literature also suggests that companies can achieve financial flexibility through either spare debt capacity or substantial cash balances (Iona and Leonida, 2016). While the COVID-19 pandemic has caused a disruption in the commercial paper market, the companies that still have the ability to borrow funds have an obvious competitive advantage compared to peers (Larcker et al., 2020). Zaid et al. (2020) point out that both equity and bond issues might be important financial sources for enterprises during the COVID-19 outbreak. If the numerous government calls for dividend cuts would be accepted by shareholders, a prudently strong cash position remaining within a company might be an important advantage during the crisis (Paine, 2020).

Scholars have started to debate the issue of eventual government support to cover firms' liquidity shortages. Businesses have been seen traditionally as profit-driven economic players while governments are perceived as being political actors encumbered with the responsibility of societal development (Chijoke-Mgbame et al., 2020). The coronavirus pandemic has contributed to our recognition of companies' dependence on the wider environment, including governmental support. In contrast, although governments have exerted unprecedented powers during the COVID-19 outbreak, their interference has been 
limited so far. As an example, they have not commonly taken equity stakes in the companies that received financial assistance from them (Levy, 2020). May and Mackin (2020) argue that large organisations with highly skilled leadership and wealthy owners that find themselves in need of government-backed support should be held accountable; top managers should be replaced and shareholders suffer the market's accounting for the lack of ability to better react to the pandemic.

\subsection{Country-specific factors and company performance under COVID-19 conditions}

Among the first issues to be addressed by academic scholars were the global macroeconomic responses occurring alongside stock market reactions to COVID-19 outbreaks in particular countries. The findings of Al-Awadhi et al. (2020) indicate that the daily growth in both the total confirmed cases and deaths caused by the pandemic have significant negative effects on the returns of the Chinese stock market. Furthermore, no previous infectious outbreak has affected the American stock market as markedly as has the COVID-19 pandemic. This has been because of federal and state government restrictions placed on commercial activity, voluntary social distancing and powerful effects upon a service-oriented economy (Baker et al., 2020).

The literature highlights the unprecedented importance of government policy during the COVID-19 crisis (Brousselle et al., 2020). The size of the shock will be determined by, among other factors, the measures that are taken by countries to avoid large-scale contagion and to limit the geographical area of spread (Baldwin and Weder di Mauro, 2020). The recent COVID-19 outbreak has been deemed a global health emergency with a direct, worldwide impact upon the institutional nature of health care and public support infrastructure (Sohrabi et al., 2020). As pointed out by Jinjarak et al. (2020), economic modelling of a pandemic should include the ability of government policies, medical systems and society to adapt to the changing dynamics of the pandemic in question.

Early studies provide a good picture of various government initiatives applied by different countries during the COVID-19 outbreak (He and Harris, 2020). National authorities triggered a series of strict governance measures whose extent and disruptiveness were unprecedented in peacetime, including closed borders, restricted exports and leveraging on contacts with multinational corporations to divert supplies of medical equipment to local markets. Israel, as an example, employed the Mossad, its foreign intelligence agency, to secretly acquire ventilators and other necessarily supplies (Levy, 2020). The question of whether such political strategies, including economic nationalism and voluntary governance, will disappear after normalisation of the current situation remains to be answered (Vieten, 2020).

Institutional differences across countries can explain the existence of so called "country effects" as determinants of differential firm performance. As noted by North (1990), institutions are not only regulatory schemes but are also adopted as normative and cognitive collective norms of conduct, including requirements, enforcement mechanisms and incentive structures. The relevance of national institutional systems when analysing the country-specific advantages for company performance is argued by several scholars (Haxhi and Aguilera, 2017; Carneya et al., 2019).

Since the COVID-19 outbreak began, firms have started to closely monitor the major developments taking place in their markets of operations. The coffee giant Starbucks was among the first to disclose the impact of the coronavirus crisis on their sales with the closure of more than half of its stores in China, a country that represents 14\% of Starbucks' sales (Larcker et al., 2020). While firms are often perceived as persisting in their current governance and disclosure policies, they often respond quickly to macroeconomic shocks (Huang et al., 2018).

Previous studies revealed contradictory viewpoints concerning the relationship between corporate governance mechanisms and company performance (Chijoke-Mgbame et al., 2020;

| CORPORATE GOVERNANCE 
Kelly, 2020; Ahsan et al., 2021). The shareholder-centric governance model suggests that the separation of the ownership of the company from its control results in "principal-agent conflict"; the managers may prioritise their own gains over maximising value for shareholders (Jensen and Meckling, 1976; Dey, 2008). In contrast, the stakeholder theory introduced by Freeman (1984) postulates that the objectives of a firm should go beyond maximising the wealth of shareholders and incorporate the needs of all relevant stakeholders, including employees, creditors, customers, supplies and community.

Regarding corporate governance, the pandemic has highlighted the important role of wellperforming organisations in satisfying the basic needs of societies and their citizens. As pointed out by Paine (2020), company accountability should not be limited to maximising value for its own shareholders but should also incorporate that firm's eventual contributions to the well-being of different stakeholders and society in general. Furthermore, synergies obtained through the co-operation of a firm's stakeholders might increase the chances of company survival and ensure a future competitive position (Chijoke-Mgbame et al., 2020).

Stubbs et al. (2021) highlighted the inequality between different counties regarding their possibilities of financing public policy measures capable of supporting businesses during the COVID-19 outbreak. While strong economies have started to defend their currencies in light of capital outflows, poor nations increasingly have no choice but to seek financial support from the global multilateral institutions. This help, however, has been limited so far (UNCTAD, 2020). Currently, the institutions of the global financial safety network have fallen short in disbursing liquidity, providing only $12.6 \%$ of available financing for emerging markets across these institutions (Stubbs et al., 2021, p. 6).

\subsection{Summary and hypothesis formulation}

Given the ambiguity of previous findings, the study's three hypotheses are proposed as null-forms:

H01. Firm-specific characteristics do not have an impact on company performance during the COVID-19 outbreak.

H02. Financial sources have no impact on company performance during the COVID-19 outbreak.

H03. Country-specific factors have no impact on company performance during the COVID-19 outbreak.

\section{Research design and methodology}

\subsection{Sample and data collection}

A data set, collected by the WBES [2] and measuring the impact of the COVID-19 pandemic on businesses, has been analysed. WBES data has been used widely in economics and development economic studies and is now beginning to be used in business studies (Golubeva, 2017; Carneya et al., 2019).

Answers provided by 5,730 respondents from 13 countries were collected during the period of 19 May-17 July 2020 as the first step of the WBES project. Classification of countries into groups was accomplished according to the gross national income (GNI) per capita. The impact of COVID-19 in the sample ranges from 129 to 57,009 cases per million, from $2 \%$ to $65.8 \%$ of firms being closed because of the epidemic and with a monthly sales downsize ranging from $28.1 \%$ to $56 \%$ compared to a one year ago period. The sampling is stratified and random with replacement, structured to be representative of the country-level with respect to firm size, business sector and geographic region. This study examines a balanced data set which serves our research purpose of investigating the impact of the 
firm-, finance- and country-specific factors on company performance during the COVID-19 outbreak. Table 1 summarises the information on countries.

\subsection{Variables and their definitions}

Consistent with the literature review, several variables have been chosen. In our study, we use two dependent variables to measure companies' performances. Firstly, we have conceived an innovative approach to COVID-19 from the perspective of performance measures by proposing an indicator that measures the percentage of firms confirmed as being opened, temporarily closed or permanently closed because of the COVID-19 outbreak. We justify this introduction by the importance of companies surviving during the period of rapidly escalated uncertainty (Kraus et al., 2020; Larcker et al., 2020). Secondly, we follow the recommendation of Zaheer (1995) and Carneya et al. (2019) to use labour productivity as a measure of company performance.

Based on an extensive review of previous literature, we assume that several firmspecific characteristics impact company performance during the COVID-19 pandemic, including sector, size and export-orientation. Inspired by literature on the dynamic nature of the pandemic and its business impacts (such as Kells, 2020), we introduce a proxy representing changes in demand for a particular firm's products and an indication of whether a firm has adjusted its production in response to the COVID-19 outbreak.

The financial variables drawn from the literature on capital structure include:

- number of weeks a firm will be able to remain open if its sales cease;

- equity being the main source of finance;

- loans being the main source of finance; and

- national or local government financial support in response to the crisis.

Table 1 Classification of countries and impact of COVID-19 on these economies

\begin{tabular}{|c|c|c|c|c|c|c|}
\hline Country & GNI per capita (2019) & $\begin{array}{l}\text { World Bank } \\
\text { classification of } \\
\text { economies }\end{array}$ & $\begin{array}{l}\text { No. of } \\
\text { respondents } \\
\text { in survey }\end{array}$ & $\begin{array}{l}\text { COVID19 no. } \\
\text { of cases per } \\
\text { million }\end{array}$ & $\begin{array}{l}\text { Closed firms, } \\
\text { permanently or } \\
\text { temporarily (\%) }\end{array}$ & $\begin{array}{c}\text { Change in monthly } \\
\text { sales compared to one } \\
\text { year ago }(\%)\end{array}$ \\
\hline Albania & 5,240 & Upper-middle-income & 347 & 20,264 & 9.7 & -51.6 \\
\hline Chad & 700 & Low-income & 132 & 129 & 65.8 & -37.6 \\
\hline Cyprus & 27,710 & High-income & 207 & 25,139 & 6.7 & -40.2 \\
\hline Georgia & 4,740 & Upper-middle-income & 614 & 57,009 & 15.5 & -47.1 \\
\hline Greece & 20,320 & High-income & 553 & 13,321 & 2.0 & -37.0 \\
\hline Guinea & 950 & Low-income & 136 & 1,045 & 24.1 & -55.5 \\
\hline Italy & 34,460 & High-income & 501 & 34,851 & 17.7 & -47.3 \\
\hline Moldova & 3,930 & Low-middle income & 286 & 35,900 & 14.1 & -57.1 \\
\hline Niger & 560 & Low-income & 125 & 137 & 11.9 & -56.0 \\
\hline Russia & 11,260 & Upper-middle-income & 1,191 & 21,430 & 8.9 & -28.1 \\
\hline Togo & 690 & Low-income & 111 & 439 & 13.6 & -44.7 \\
\hline Zambia & 1,450 & Low-middle income & 578 & 1,127 & 25.5 & -43.0 \\
\hline Zimbabwe & 1,390 & Low-middle income & 949 & 933 & 11.9 & -53.9 \\
\hline \multicolumn{7}{|c|}{$\begin{array}{l}\text { Notes: The World Bank classifies the world's economies into four income groups - high (US } \$ 12,536 \text { or more), upper-middle (US } \\
\$ 4,046-U S \$ 12,535) \text {, lower-middle (US } \$ 1,036 \text { to US } \$ 4,045) \text { and low (US } \$ 1,035 \text { or less). The assignment is based on GNI per capita } \\
\text { (current US } \$ \text { ), calculated using the Atlas method. Source: https://blogs.worldbank.org/opendata/new-country-classifications-income- } \\
\text { level-2019-2020. Data for COVID19 number of cases per million is sourced from https://ourworldindata.org/coronavirus-data (accessed } \\
30 \text { December 2020). The percentage of closed firms, permanently or temporarily and percentage of change in monthly sales compared } \\
\text { to one year ago, are calculated by the authors }\end{array}$} \\
\hline
\end{tabular}


Inclusion of country-specific factors has been inspired by institutional theory and its importance for corporate governance (Chijoke-Mgbame et al., 2020). Additionally, early studies on COVID-19 suggest the unprecedented importance of macro-economic and institutional factors for company performance (Al-Awadhi et al., 2020; Sohrabi et al., 2020; Jinjarak et al., 2020). The country-specific variables are the level of economic development and the number of COVID-19 cases per million of inhabitants.

Further, we made a search for measurements of the corporate governance infrastructure. The literature suggests that a single institutional domain or characteristic by itself might not be sufficient to explain corporate governance outcomes (Haxhi and Aguilera, 2017; Carneya et al., 2019; Ahsan et al., 2021). We, therefore, chose to apply the World Corporate Governance Index (WCGI), [3] which compares corporate governance infrastructures in 150 countries and includes factors such as independent board membership, social responsibilities, banking supervisory authorities, political rights, corruption and personal freedom.

The variables selected for this study are summarised in Table 2.

Table 2 Description of variables, acronyms and assigned codes

Variable and acronym

Dependent variables (PERFORM)

IMPACT

\section{SALESEMPL}

Firm-specific factors (FIRM)

SECTOR

SIZE

EXPORTERS

DEMAND

\section{ADJUSTED}

Financial sources (FINANCE)

BUFFER

EQUITY

LOANS

GOVSUPPORT

Country-specific factors (COUNTRY)

ECONOMY

COVID19

CORPGOV
Description and codes

Impact on firms is reflected as follows: firms confirmed as being permanently closed (code 0); temporarily closed (code 1); open (code 2) during the COVID-19 outbreak

Change in monthly sales per employee during COVID-19 compared to the respective month of the previous year (\%)

Sectors are grouped as follows: 1 - manufacturing; 2 - retail sector; 3 - other

Number of employees - permanent full-time workers end of December 2019

1 - Exporter (10\% or more of sales exported directly); 2 - nonexporter

Market demand under COVID-19 outbreak for this firm's products and services: 0 - decreased; 1 - remain the same; 2 - increased Indication whether a firm has adjusted or converted, partially, or fully, its production or the services in response to the COVID-19 outbreak: 0 - no; 1 -yes

The number of weeks that this firm will be able to remain open if its sales ceased as of today

Since the outbreak of COVID-19, the main source of finance was equity and retained earnings of this company: 0 - no; 9 -yes

Since the outbreak of COVID-19, the main source of finance was loan (s) from commercial banks and non-banking financial institutions: 0 no; 2 -yes

Since the outbreak of COVID-19, national or local government support to a firm: 0 - no support; 1 - no support but expected within 3 months; 2 - received support

Classification of countries in line with the World Bank's grouping of world's economies: 1 - low income; 2 - low middle income; 3 - upper middle income; 4 - high income

Number of cases in a country per million inhabitants

Inclusion of a country is coded as 1 , non-inclusion is coded as 0 (WCGI, 2019) 


\subsection{Model specification}

To analyse the performance of firms under COVID-19 outbreak, we apply the following OLS regression model:

$$
\text { PERFORM }{ }_{j}=\alpha+\beta_{1 *}(\text { FIRM })_{j}+\beta_{2 *}(\text { FINANCE })_{j}+\beta_{3 *}(\text { COUNTRY })_{j}+\varepsilon_{j}
$$

where $\alpha$ is a constant; $\beta_{1}-\beta_{3}$ are vectors of parameters to be estimated; $\epsilon_{\mathrm{j}}$ is the stochastic error term; the dependent variable PERFORM is a measure of performance for firm $j$; the vector FIRM represents firm-specific factors; the vector FINANCE includes various financial sources; and the country-specific factors are labelled as vector COUNTRY. Two variables are suggested as proxies for PERFORM: IMPACT and SALESEMP. The vector FIRM includes: SECTOR, SIZE, EXPORTERS, DEMAND and ADJUSTED. The vector FINANCE includes: BUFFER, EQUITY, LOANS and GOVSUPPORT. The vector COUNTRY includes ECONOMY, COVID19 and CORPGOV.

Additional robustness tests have been performed by the authors, successfully confirming the research findings. Calculations are not included in the paper because of limitations of space, but they are available from the corresponding author.

\section{Results presentation and analysis}

Descriptive statistics are summarised in Table 3.

A bivariate analysis was applied using both the Pearson and the Spearman correlation coefficients. The summary of the outcomes is presented in Table 4. The coefficients of the pair-wise correlation among variables in our study are generally low and range between -0.228 and 0.734 , below the typical concern threshold of the multicollinearity indication level. The assumption of no perfect multicollinearity among input variables was additionally checked by using the variance inflation factor (VIF). In our study, the VIF values range from 1.017 to 1.629. The model could thus be used without variables being removed. The Durbin-Watson statistic measuring autocorrelation, where successive residuals are correlated, ranges between 1.766 and 1.834, indicating no or very minor autocorrelation (Table 5).

Table 5 presents the regression estimates concerning the influence of firm-, financial- and country-specific characteristics on companies' performances during the COVID-19 pandemic.

\section{Table 3 Descriptive statistics}

\begin{tabular}{|c|c|c|c|c|c|}
\hline Variables & N & Minimum & Maximum & Mean & Std. deviation \\
\hline IMPACT & 5,324 & 0.00 & 2.00 & 1.81 & 0.46 \\
\hline SALESEMPL & 5,057 & -100.00 & 80.00 & -4.53 & 9.91 \\
\hline SECTOR & 5,324 & 1.00 & 3.00 & 1.85 & 0.88 \\
\hline SIZE & 5,066 & 0.00 & $20,000.00$ & 79.89 & 422.25 \\
\hline EXPORTERS & 4,898 & 1.00 & 2.00 & 1.86 & 0.35 \\
\hline DEMAND & 5,072 & 0.00 & 2.00 & 0.33 & 0.61 \\
\hline ADJUSTED & 5,140 & 0.00 & 2.00 & 0.41 & 0.49 \\
\hline BUFFER & 4,312 & 0.00 & 260.00 & 6.56 & 9.83 \\
\hline EQUITY & 5,293 & 0.00 & 9.00 & 2.17 & 3.85 \\
\hline LOANS & 5,308 & 0.00 & 2.00 & 0.10 & 0.30 \\
\hline GOVSUPPORT & 5,116 & 0.00 & 2.00 & 0.46 & 0.80 \\
\hline ECONOMY & 5,324 & 1.00 & 4.00 & 2.77 & 0.86 \\
\hline COVID19 & 5,324 & 129.00 & $57,009.00$ & $20,012.04$ & $17,740.24$ \\
\hline CORPGOV & 5,324 & 0.00 & 1.00 & 0.33 & 0.47 \\
\hline
\end{tabular}




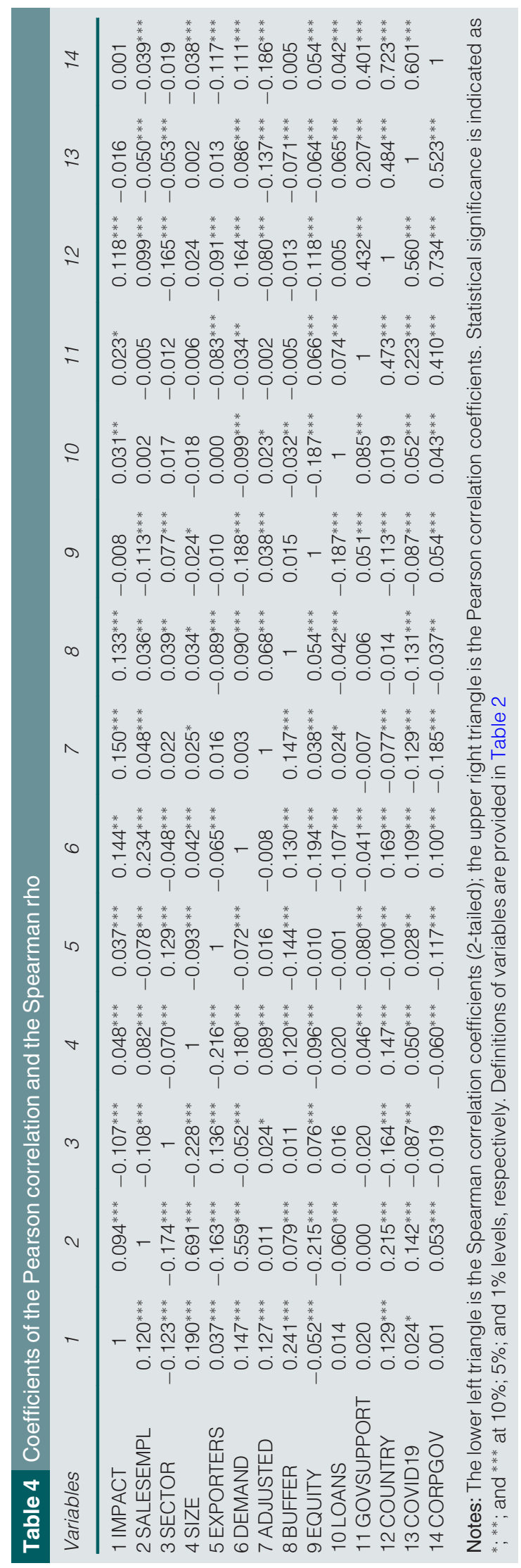


Table 5 Multiple regression results

\begin{tabular}{|c|c|c|c|c|c|c|}
\hline \multirow[t]{2}{*}{ Variables } & \multicolumn{3}{|c|}{ Model 1 (IMPACT as a dependent variable) } & \multicolumn{3}{|c|}{ Model 2 (SALESEMPL as a dependent variable) } \\
\hline & Coefficients & Std. error & t-value & Coefficients & Std. error & t-value \\
\hline \multicolumn{7}{|l|}{ Firm-specific } \\
\hline SECTOR & $-0.028^{* * *}$ & 0.006 & -4.921 & $-0.795^{* * *}$ & 0.170 & -4.688 \\
\hline SIZE & $3.118 \mathrm{E}-5^{*}$ & 0.000 & 1.956 & $0.003^{* * *}$ & 0.001 & 4.921 \\
\hline EXPORTERS & $0.056^{* * *}$ & 0.014 & 3.918 & $-0.978^{* *}$ & 0.430 & -2.275 \\
\hline DEMAND & $0.041^{* * *}$ & 0.008 & 4.915 & $3.568^{* * *}$ & 0.250 & 14.291 \\
\hline ADJUSTED & $0.031^{* * *}$ & 0.010 & 3.145 & 0.381 & 0.300 & 1.272 \\
\hline \multicolumn{7}{|l|}{ Financial factors } \\
\hline BUFFER & $0.001^{* * *}$ & 0.000 & 2.952 & 0.020 & 0.014 & 1.407 \\
\hline EQUITY & $-0.004^{* * *}$ & 0.001 & -3.099 & $0.079^{* *}$ & 0.040 & 1.998 \\
\hline LOANS & -0.007 & 0.017 & -0.405 & $2.229^{* * *}$ & 0.499 & 4.472 \\
\hline GOVSUPPORT & -0.009 & 0.007 & -1.373 & -0.045 & 0.205 & -0.220 \\
\hline \multicolumn{7}{|l|}{ Country-specific } \\
\hline ECONOMY & $0.101^{* * *}$ & 0.010 & 10.585 & $2.486^{* * *}$ & 0.287 & 8.672 \\
\hline COVID19 & $-4.081 E-7$ & 0.000 & -1.157 & $-2.977 \mathrm{E}-5^{* * *}$ & 0.000 & -2.761 \\
\hline CORPGOV & $-0.081^{* * *}$ & 0.018 & -4.565 & $-4.047^{* * *}$ & 0.536 & -7.551 \\
\hline Constant (model) & $1.571^{* * *}$ & 0.037 & 42.019 & $-8.450^{* * *}$ & 1.120 & -7.547 \\
\hline $\mathrm{R}$ (model) & 0.280 & & & 0.329 & & \\
\hline F-statistics (model) & $26.383^{* * *}$ & & & $36.847^{* * *}$ & & \\
\hline Durbin-Watson & 1.766 & & & 1.834 & & \\
\hline
\end{tabular}

Notes: Model 1 assumes IMPACT to be a dependent variable. Model 2 assumes SALESEMPL to be a dependent variable. Definitions of variables are summarised in Table 2 . Statistical significance is indicated as *; **; and ${ }^{* * *}$ at the $10 \% ; 5 \%$; and $1 \%$ levels, respectively

The study found that sector, firm size, participation in exports and market demand all impact significantly the performances of companies during the COVID-19 outbreak. We confirm, therefore, findings suggested by early literature on the importance of sector (Bartik et al., 2020) and size (Ichev and Marinč, 2018) on company performance. Market demand for a firm's products and services during the COVID-19 outbreak is statistically significant at the $1 \%$ level in both models. Interestingly, the indicator EXPORTERS has been confirmed as significant but with different signs in the two models. This finding does not contradict previous literature that suggests a certain ambiguity in the possible impact of exporting activities on company performance (Amiti and Weinstein, 2011; Van Biesebroeck et al., 2016). Although an export activity commonly affects company performance, the direction of that impact probably depends on the configuration of variables that are selected to represent performance outcomes.

The study has demonstrated the importance of equity for company performance during the coronavirus crisis, a result which is statistically significant in both models. The empirical evidence does not fully support either the pecking order or the agency theories. The tradeoff theory might be the closest one to explain our empirical results, as equity can be chosen before debt because of the raised costs of bankruptcy under COVID-19 circumstances.

We also found that the liquidity buffer is a significant factor when the closure/openness of companies is used as a dependent variable, while the loan financing becomes more important when changes in productivity are assessed. This empirical outcome can be explained as follows: when the closure of companies is considered, the existing liquidity buffer can postpone such a decision; at the same time, banks can hardly consider lending to a closed company but can offer loans to the performing entities.

So far, a financial contribution by a government has not been a significant financing source for supporting companies during the COVID-19 outbreak. In view of sufficient funding being established to support firms during the crisis, this question needs clarifications by future scholars. 
The study also confirms the importance of country-specific characteristics for company performance during the coronavirus pandemic, including the level of economic development and corporate governance infrastructure in a particular country. A somewhat surprising finding is the strong effect of the COVID-19 factor on changes in the productivity of firms alongside its non-significant impact on the closure/openness of enterprises. One eventual explanation is that possible government aid has been directed to support the most vulnerable businesses that strive for survival.

There are two dependent variables chosen for this study. Firstly, we have conceived an innovative approach from the perspective of performance measures by suggesting an indicator that measures the percentage of firms confirmed as being opened, temporarily closed or permanently closed because of the COVID-19 outbreak. It is not possible currently to conclude whether this indicator is a relevant one in business studies in the long run. Additional studies are required with the application of various metrics and crosssectional data.

We also used a more traditional indicator of performance (change in sales per employee) as a second dependent variable in our study. Although the R factor (explanation capacity of the model) is higher for Model 2 (0.329) compared to Model $1(0.280)$, both models point out the significance of 8 variables out of 12 factors, which allows for approximately similar conclusions to be drawn from these two regressions.

\section{Conclusions}

Both performance accountability and corporate governance have been severely tested by the crisis. Whether COVID-19 is truly an inflection point for countries and firms is yet to be seen but there is no doubt that the pandemic has challenged core premises of several theoretical foundations in ways that have important implications for the future.

The main contribution of this study is the development of a performance model for enterprises during the COVID-19 crisis. Although this paper is far from the final word on these questions, it presents an initial regression model for tracking the performances of firms during the COVID-19 outbreak.

The second contribution is that we combine investigation of traditional performance measurements with the testing of relatively novel variables (such as business closures during COVID-19 and whether firms respond to the pandemic by adjusting their business activities).

Finally, this study is among the first to investigate the simultaneous impact of indicators, drawn from multiple theories (i.e. firm-specific variables, financial sources and countryspecific factors) on firms' performances during the coronavirus pandemic with crossnational empirical data.

Given that COVID-19 might have a long-term effect, the study can serve as a building block for further research into the subject. Specifically, this article encourages future researchers to apply multiple theories and examine their relevance to company performance. Moreover, to gain a comprehensive understanding of the impact of COVID-19, we advise testing various proxies, including the novel ones. It is quite astonishing that a simple measurement of closure/openness of firms during the COVID-19 crisis leads to conclusions comparable to outcomes resulting from the application of more sophisticated metrics like productivity (change of sales per employee).

The vulnerability of particular private firms, industry sectors and countries to infectious diseases such as COVID-19 should be recognised and managed by policymakers and corporate professionals, offering various subsidies and preferential policies. COVID-19 also contributes to our recognition of firms' dependence on the wider environment, including governments' support and interventions. Although countries have reasserted their authority 
during the COVID crisis, it seems that companies' and governments' financing responsibilities and their relationships with enterprises' performance outcomes, need to be re-designed after the COVID-19 crisis has passed.

One limitation of this study is that, at the time of writing, the COVID-19 pandemic is ongoing, with a possible eventual third wave of the outbreak yet to follow. Furthermore, the process of empirical data collection for different countries through the enterprise surveys by the World Bank is continuing and future analysis of the final global data set might affect the conclusions drawn from this research. Despite these limitations, this study contributes to the existing literature by adding new evidence concerning the COVID-19 outbreak in a global context: it might assist regulatory bodies, policymakers and companies in their formulation of public and corporate governance strategies concerning future emergency preparedness and responses.

\section{Notes}

1. The data is available at www.enterprisesurveys.org/en/covid-19

2. www.enterprisesurveys.org/en/covid-19

3. Source: www.saharating.com/ saharati/en/world-corporate-governance-index/

\section{References}

Ahsan, T., Mirza, S.S., Al-Gamrh, B., Bin-Feng, C. and Rao, Z.U.R. (2021), "How to deal with policy uncertainty to attain sustainable growth: the role of corporate governance", Corporate Governance: The International Journal of Business in Society, Vol. 21 No. 1, pp. 78-91.

Al-Awadhi, A.M., Alsaifi, K., Al-Awadhi, A. and Alhammadi, S. (2020), "Death and contagious infectious diseases: impact of the COVID-19 virus on stock market returns", Journal of Behavioral and Experimental Finance, Vol. 27, pp. 2-5.

Amiti, M. and Weinstein, D.E. (2011), "Exports and financial shocks", The Quarterly Journal of Economics, Vol. 126 No. 4, pp. 1841-1877.

Baldwin, R. and Weder di Mauro, B. (2020), Economics in the Time of COVID-19, CEPR Press.

Baker, S. Bloom, N. Davis, S.J. Kost, K. Sammon, M. and Viratyosin, T. (2020), "The unprecedented stock market reaction to COVID-19", The Review of Asset Pricing Studies raaa008, on-line version.

Barro, R.J., Ursúa, J.F. and Weng, J. (2020), "The coronavirus and the great influenza pandemic: lessons from the 'Spanish flu' for the coronavirus's potential effects on mortality and economic activity", working paper, National Bureau of Economic Research, No. 26866.

Bartik, A.W., Bertrand, M., Cullenc, Z., Glaeser, E.L., Luca, M. and Stanton, C. (2020), "The impact of COVID-19 on small business outcomes and expectations", Proceedings of the National Academy of Sciences, Vol. 117 No. 30, pp. 17656-17666.

Bongini, P., Cucinelli, D., Battista, M.L.D. and Nieri, L. (2019), "Profitability shocks and recovery in time of crisis evidence from European banks", Finance Research Letters, Vol. 30, pp. 233-239.

Brousselle, A., Brunet-Jailly, E., Kennedy, C., Phillips, S.D., Quigley, K. and Roberts, A. (2020), "Beyond COVID-19: five commentaries on reimagining governance for future crises and resilience", Canadian Public Administration, Vol. 63 No. 3, pp. 369-408.

Carneya, M., Estrin, S., Liang, Z. and Shapiro, D. (2019), "National institutional systems, foreign ownership and firm performance: the case of understudied countries", Journal of World Business, Vol. 54 No. 4, pp. 244-257.

Chatzinas, G. and Papadopoulos, S. (2018), "Trade-off vs. pecking order theory: evidence from Greek firms in a period of debt crisis", International Journal of Banking, Accounting and Finance, Vol. 9 No. 2, pp. 170-191.

Chen, L.-J. and Chen, S.-Y. (2011), "The influence of profitability on firm value with Capital structure as the mediator and firm size and industry as moderators", Investment Management and Financial Innovations, Vol. 8 No. 3, pp. 121-129. 
Chijoke-Mgbame, A.M., Mgbame, C.O., Akintoye, S. and Ohalehi, P. (2020), "The role of corporate governance on CSR disclosure and firm performance in a voluntary environment", Corporate Governance: The International Journal of Business in Society, Vol. 20 No. 2, pp. 294-306.

de Jong, A., Verbeek, M. and Verwijmeren, P. (2010), "The impact of financing surpluses and large financing deficits on tests of the pecking order theory”, Financial Management, Vol. 39 No. 2, pp. 733 -756.

Devinney, T.M., Yip, G.S. and Johnson, G. (2010), "Using frontier analysis to evaluate company performance", British Journal of Management, Vol. 21 No. 4, pp. 921-938.

Dey, A. (2008), "Corporate governance and agency conflicts", Journal of Accounting Research, Vol. 46 No. 5, pp. 1143-1181.

Fama, E.F. and French, K.R. (2002), "Testing trade-off and pecking order predictions about dividends and debt", Review of Financial Studies, Vol. 15 No. 1, pp. 1-33.

Fernández-Temprano, M.A. and Tejerina-Gaite, F. (2020), "Types of director, board diversity and firm performance", Corporate Governance: The International Journal of Business in Society, Vol. 20 No. 2, pp. 324-342.

Ferreira, A. and Otley, D. (2009), "The design and use of performance management systems: an extended framework for analysis", Management Accounting Research, Vol. 20 No. 4, pp. 263-282.

Freeman, R.E. (1984), Strategic Management: A Stakeholder Approach, Pitman, Boston.

Giovannoni, E. and Pia Maraghini, M. (2013), "The challenges of integrated performance measurement systems: integrating mechanisms for integrated measures", Accounting, Auditing \& Accountability Journal, Vol. 26 No. 6, pp. 978-1008.

Golubeva, O. (2017), "Does perception of business climate differ between foreign and local investors? A firm-level study of transition economies in Eastern Europe and Central Asia", Applied Economics and Finance, Vol. 4 No. 2, pp. 113-128.

Goodell, J.W. (2020), "COVID-19 and finance: agendas for future research", Finance Research Letters, Vol. 35, pp. 1-5.

Hassan, T.A., Hollander, S., Lent, L. and Tahoun, A. (2020), "Firm-level exposure to epidemic diseases covid-19, SARS, and H1N1", Working paper, National Bureau of Economic Research, No. 26971.

Haxhi, I. and Aguilera, R.V. (2017), "An institutional configurational approach to cross-national diversity in corporate governance”, Journal of Management Studies, Vol. 54 No. 3, pp. 261-303.

He, H. and Harris, L. (2020), "The impact of covid-19 pandemic on corporate social responsibility and marketing philosophy", Journal of Business Research, Vol. 116, pp. 176-182.

Henri, J.F. (2004), "Performance measurement and organizational effectiveness: bridging the gap", Managerial Finance, Vol. 30 No. 6, pp. 93-123.

Huang, Z., Gao, W. and Chen, L. (2018), "Does the external environment matter for the persistence of firms' debt policy?", Finance Research Letters, Vol. 32, pp. 2-9.

Ichev, R. and Marinč, M. (2018), "Stock prices and geographic proximity of information: evidence from the Ebola outbreak”, International Review of Financial Analysis, Vol. 56, pp. 153-166.

Iona, A. and Leonida, L. (2016), "Suboptimal financial policies and executive ownership in the UK: evidence from a pre-crisis", Corporate Governance: The International Journal of Business in Society, Vol. 16 No. 1, pp. 187-210.

lyke, B.N. (2020), "The disease outbreak channel of exchange rate return predictability: evidence from COVID-19", Emerging Markets Finance and Trade, Vol. 56 No. 10, pp. 2277-2297.

Jensen, M.C. and Meckling, W.H. (1976), "Theory of the firm: managerial behavior, agency costs and ownership structure”, Journal of Financial Economics, Vol. 3 No. 4, pp. 305-360.

Jinjarak, Y., Ahmed, R., Nair-Desai, S., Xin, W. and Aizenman, J. (2020), "Accounting for global COVID-19 diffusion patterns”, working paper, National Bureau of Economic Research, No. 27185.

Kells, S. (2020), "Impacts of COVID-19 on corporate governance and assurance, international finance and economics, and non-fiction book publishing: some personal reflections", Journal of Accounting \& Organizational Change, Vol. 16 No. 4, pp. 629-635.

Kelly, M. (2020), "COVID-19: the ultimate governance challenge", Internal Auditor, June, pp. 56-57. 
Kraus, A. and Litzenberger, R.H. (1973), "A state-preference model of optimal financial leverage", The Journal of Finance, Vol. 28 No. 4, pp. 911-922.

Kraus, S., Clauss, T., Breier, M., Gast, J., Zardini, A. and Tiberius, V. (2020), "The economics of COVID-19: initial empirical evidence on how family firms in five European countries cope with the corona crisis", International Journal of Entrepreneurial Behavior \& Research, Vol. 26 No. 5, pp. 1067-1092.

Larcker, D.F. Lynch, B. Tayan, B. and Taylor, D.J. (2020), "The spread of COVID-19 disclosure”, Stanford Closer Look Series, June, pp. 1-15.

Leary, M.T. and Roberts, M.R. (2010), "The pecking order, debt capacity and information", Journal of Financial Economics, Vol. 95 No. 3, pp. 332-355.

Levy, D.L. (2020), "COVID-19 and global governance”, Journal of Management Studies, on-line version, p. 1-5.

Marsden, C. (2010), "Economics, the financial crisis and corporate responsibility", Corporate Governance: The International Journal of Business in Society, Vol. 10 No. 4, pp. 360-364.

Mather, P. (2020), "Leadership and governance in a crisis: some reflections on COVID-19", Journal of Accounting \& Organizational Change, Vol. 16 No. 4, pp. 579-585.

May, D. and Mackin, C. (2020), "Responding to the COVID-19 crisis: public policy and corporate governance considerations", Challenge, Vol. 63 No. 4, pp. 234-238.

Melnyk, S.A., Bititci, U., Platts, K., Tobias, J. and Andersen, B. (2014), "Is performance measurement and management fit for the future?”, Management Accounting Research, Vol. 25 No. 2, pp. 173-186.

Miller, M.H. (1977), "Debt and taxes", The Journal of Finance, Vol. 32 No. 2, pp. 261-275.

Myers, S.C. (1984), "The Capital structure puzzle", The Journal of Finance, Vol. 39 No. 3, pp. 575-592.

Myers, S. and Majluf, N. (1984), "Corporate financing decisions when firms have investment information that investors do not", Journal of Financial Economics, Vol. 13 No. 2, pp. 187-221.

North, D. (1990), Institutions, Institutional Change and Economic Performance, Cambridge University Press, New York, NY.

Obrenovic, B., Du, J., Godinic, D., Tsoy, D., Aamir, M., Khan, S. and Jakhongirov, I. (2020), "Sustaining enterprise operations and productivity during the COVID-19 pandemic: enterprise effectiveness and sustainability model", Sustainability, Vol. 12 No. 15, pp. 1-27.

Paine, L.S. (2020), "Covid-19 is rewriting the rules of corporate governance", Harvard Business Review, pp. 2-11, October 06.

Parker, L.D. (2020), "The COVID-19 office in transition: cost, efficiency and the social responsibility business case", Accounting, Auditing \& Accountability Journal, Vol. 33 No. 8, pp. 1943-1967.

PWC (2021), "COVID-19: some considerations relating to corporate governance", available at: www.pwc. $\mathrm{com} / \mathrm{mt} / \mathrm{en} /$ publications/tax-legal/covid-19-some-considerations.html

Rinaldi, L., Cho, C.H., Lodhia, S.K., Michelon, G. and Tilt, C.A. (2020), "Accounting in times of the COVID-19 pandemic: a forum for academic research", Accounting Forum, Vol. 44 No. 3, pp. 180-183.

Shen, H., Fu, M., Pan, H., Yu, Z. and Chen, Y. (2020), "The impact of the COVID-19 pandemic on firm performance", Emerging Markets Finance and Trade, Vol. 56 No. 10, pp. 2213-2230.

Sohrabi, C., Alsafi, Z., O’Neill, N., Khan, M., Kerwan, A., Al-Jabir, A., losifidis, C. and Agha, R. (2020), "World health organization declares global emergency: a review of the 2019 novel coronavirus (COVID-19)", International Journal of Surgery, Vol. 76, pp. 71-76.

Stubbs, T., Kring, W., Laskaridis, C., Kentikelenis, A. and Gallagher, K. (2021), "Whatever it takes? The global financial safety net, covid-19, and developing countries", World Development, Vol. 137, p. 105171.

UNCTAD (2020), "From the great lockdown to the great meltdown: developing country debt in the time of covid-19", Trade and Development Report Update, Geneva.

Van Biesebroeck, J., Konings, J. and Volpe Martincus, C. (2016), " "Did export promotion help firms weather the crisis?", Economic Policy, Vol. 31 No. 88, pp. 653-702.

Vieten, U.M. (2020), "The 'new normal' and 'pandemic populism': the covid-19 crisis and anti-hygienic mobilisation of the far-right", Social Sciences, Vol. 9 No. 9, p. 165

World Health Organisation (WHO) (2021), "WHO coronavirus disease (COVID-19) dashboard", available at: https://covid19.who.int/ 
Xiong, H., Wu, Z., Hou, F. and Zhang, J. (2020), "Which firm-specific characteristics affect the market reaction of Chinese listed companies to the COVID-19 pandemic?", Emerging Markets Finance and Trade, Vol. 56 No. 10, pp. 2231-2242.

Zaheer, S. (1995), "Overcoming the liability of foreignness", Academy of Management Journal, Vol. 38 No. 2, pp. 341-363.

Zaid, M.A.A., Wang, M., Abuhijleh, S.T.F., Issa, A., Saleh, M.W.A. and Ali, F. (2020), "Corporate governance practices and Capital structure decisions: the moderating effect of gender diversity", Corporate Governance: The International Journal of Business in Society, Vol. 20 No. 5, pp. 939-964.

\section{Further reading}

Schepers, S. (2010), "Business-government relations: beyond lobbying", Corporate Governance: The International Journal of Business in Society, Vol. 10 No. 4, pp. 475-483.

\section{About the author}

Olga Golubeva, based at the Department of Accounting of Stockholm Business School, Stockholm University, is the contacting author. Dr Golubeva's academic career is combined with about 20 years of management experience in the investment and corporate banking. She is responsible for courses "Company analysis and valuation", "Consolidated financial accounting and audit", "Advanced research methods in accounting and operation management", "Accounting for Executive MBA". Dr Golubeva is a member of the Swedish Society for Financial Analysts, Swedish Corporate Governance Academy and the European Accounting Association. Her research findings have been published in several peer-reviewed journals. Olga Golubeva can be contacted at: olga.golubeva@sbs.su.se

For instructions on how to order reprints of this article, please visit our website: www.emeraldgrouppublishing.com/licensing/reprints.htm

Or contact us for further details: permissions@emeraldinsight.com 